\title{
Design the Network Marketing System of the Tourism Destination under the Smart City Framework
}

\author{
Lan-lan LIU ${ }^{1}$, Qiang YU ${ }^{1}$, Jing LIU ${ }^{1}$ \\ ${ }^{1}$ The shool of economic and management, Harbin University, Harbin, China \\ (liulanlan_001@163.com)
}

\begin{abstract}
Become a Smart City is the trend development of urban cities. Tourism industry is an important industry of a city, It is a important projects of urban construction. When promoting tourism destination, the role of marketing is particularly important. To do a good job of a city's tourism publicity, need provides a new marketing mode, Tourism destination marketing system arises at the historic moment. In this article, the construction of tourism destination network marketing system is according to the travel service demand of consumers, base on the advanced information technology. In the end put forward the evaluation mechanism, ensure the effective operation of the system
\end{abstract} city

Keywords-Network Marketing; tourism destination; smart

\section{INTRODUCTION}

\section{A. Smart City}

At present, The number of Smart City projects is not less than 200. Many organizations have successively established such as ICF(Intelligent Community Forum). ICF think the Smart City is intelligence community. Smart City attaches great importance to the development of the wide area economic, rely on the intelligence information technology to promoting economic development and provide social welfare.

B. Smart City Framework

1) The things of Internet: Destination network marketing system is constructed in the framework of the smart city, "The things of Internet" is one of the signs of smart city. The establishment and application of the Internet of things, is the guarantee for the realization of technology platform, it is the key factor for the successful construction of tourism destination network marketing system.

2) Cloud computing: Cloud computing is the increase in Internet related services, use and delivery mode based on, usually via the Internet provides dynamically scalable and often virtualized resources. The amount of information involved tourism destination

network marketing system is relatively large, based on cloud computing technology, can meet the needs of large data processing and analysis.

C. Network Marketing

Network marketing is the innovation of marketing, network marketing as one of the most effective marketing model in enterprises' network operation, It brought an opportunity for the enterprises' growth. Based on the smart city system to build the tourism destination network marketing system, also is the innovation of Smart City's propaganda .

\section{FUNCTION OF TOURISM DESTINATION NETWORK MARKETING}

\section{A. Information Function}

The information function of tourism destination contains three functions of information release, information service and information feedback. Tourism destination network marketing need timely release and update the information resources on the platform, in order to help the visitors to the terminal query and collection. Information service function mainly through design all kinds of application to realize the function such as information retrieval and classification application navigation. Through monitoring and statistical data traffic, we can find out the hot topic of tourism consumption, in order to organize effective resources instant corresponding market consumer demand.

B. Take the initiative to marketing

Tourism destination marketing have the advantage of e-commerce platform. Travel consumers get the authentication service by site registration. E-commerce platform can through the E-mail address, release the information of tourism production to the registered users on a regular basis, Through statistical analysis of customer records and consumption habits, we can find out the high quality customers and Provide quality services to customers.

\section{Online Services}

Online services can provide better experience to customers. Through online communication with customers , we can more accurately give customer service accordingly, Can satisfy the personalized needs of tourist consumers. For example, online booking air tickets, train ticket or hotel accommodation reservation, and also can custom tourist attractions.

\section{MODEL}

The social public service and people's livelihood is the start point of smart city construction. Smart city surround the wisdom industry, intelligent management and construction of intelligent life. Intelligent tourism as a part of the intelligence industry, The construction of the network marketing system needs to meet the development of wisdom 
urban. The level of smart city construction determined the level of tourism destination network marketing system.

This article tries to create the tourism destination network marketing system from the perspective of technology layer, link layer, and industry layer, under the system of tourism destination network marketing system is created the model of tourism destination network marketing.

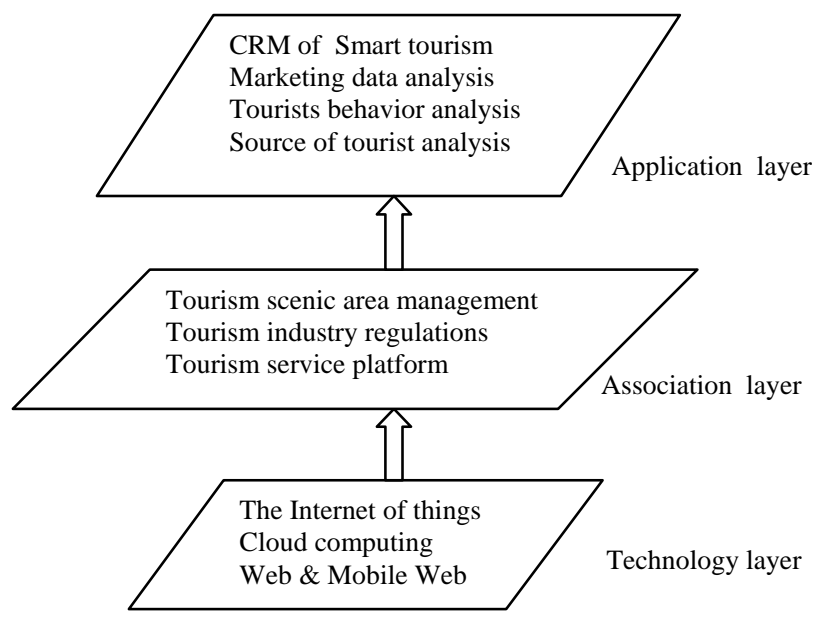

Fig.1 The model of tourism destination network marketing system.

\section{A. Customer Relationship Management}

Tourism destination customer relationship management system is base on the network platform to realize digital, timely, and dynamic communication between businesses and customers. By building the model can comprehensively collecting customer information and tracking service, to provide with quick and comprehensive high quality service to customers, improve customer satisfaction, so as to maintain existing customers and excavate new customers. The tourism destination customer relationship management system can help the tourist companies to optimize the business processes, integrate with customer service, and improve the enterprise competition power of tourist companies.

\section{B. Marketing Data Analysis}

The module of marketing data analysis obtain all kinds of marketing data, help tourist companies make marketing decisions. Constructing the Big Data Service of tourism marketing, realize the purpose of collecting marketing data, proofreading, sharing and analysis and evaluation.

Marketing data collection function is implemented by the Internet. Sales data and cost data are collected to the database center of destination network marketing. Information in the data center has been proofread, through dynamic monitoring and tracking of data comparison, find problems and timely notify the data collection module, to correct the problem. Ensure accuracy of marketing data and avoid the unnecessary cost caused by the improper data waste, thus ensuring the reliability of analysis results;

Through data sharing, can in time understanding the marketing dynamics, to help enterprises planning marketing strategy, assess the effect of marketing.

\section{Tourists Behavior Analysis}

Tourists behavior analysis use the $5 \mathrm{~W} 1 \mathrm{H}$ analysis method, include consumers(WHO); buying motives (WHY); time (WHEN); place (WHERE); the type of product(WHAT) and the way (HOW), just like the Fig.2.

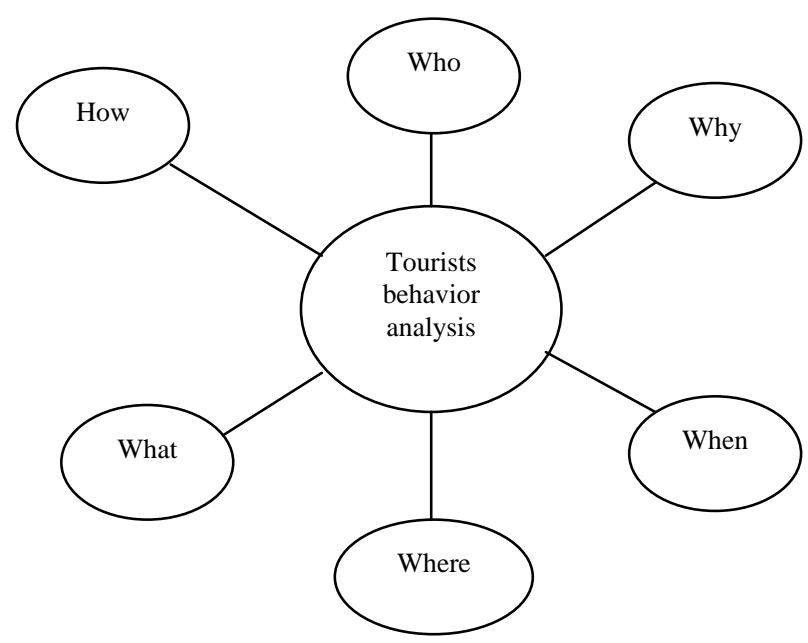

Fig. 2 The $5 \mathrm{~W} 1 \mathrm{H}$ of tourists behavior analysis.

1) Consumer(WHO): By collecting the information of consumer's gender, age, education level, cultural level and professional, make analysis of the hierarchical structure of the consumers .

2) Buying motives(WHY): The purpose of tourists travel generally includes sightseeing, visiting friends, leisure, cultural exchanges, business meetings and so on. Through the analysis of these data can find out the trend of tourism consumption motivation in different distribution, help tourism business to analysis the advantages and disadvantages of tourism products, help them fully grasp the consumption trends and motivation of the tourism consumers.

3) Time(WHEN): The time of tourists to choose travel, and the remaining time to visit a tourist destination, is the focus of the statistical model analysis. By the statistical analysis of the time, easy to grasp the trend of the time distribution of the tourist season, help the tourism business marketing prepare ahead of time.

4) Place(WHERE):To collect and summary the information of tourism consumer's choice of the scenic spot of tourism, restaurant, hotel, shopping places, can help the tourism business to find out the hot scenic spot, the tourism management and tourism business can design the classic lines to guide consumption, rational allocation of resources.

5) Type of product(WHAT): Through statistical the categories and brand of the goods sales in the scenic spot, select the supplier of competitive strength, management 
guidance the prices , supervision service, ensure the quality of product, let tourists rest assured consumption.

6) The way(HOW):To know the ways and means of tourist, formulate the corresponding marketing model, to cater to consumers' spending habits and preferences.

\section{Source of Tourist Analysis}

The number of tourists is bigger, the scale of market is greater. Through the results of the analysis and research of the source of tourists can clear the reasonable basis of regional tourism resources allocation, help tourism business to clear the direction and focus of market publicity and guidance. The regional distribution characteristics of tourist resources Determine the marketing strategy and resource allocation in different.

Seasonal factor is also an important factor in developing tourist marketing strategy. In winter, the ice and snow sport tourism is an important marketing strategy to attract the tourists of south, but the northern tourists prefer to go to the south beach to spend their holiday. This example is shows that the choices of tourist destination have different pursuit and preferences. cross regional travel tourists is a valuable resource to promote regional economic development and integration.

\section{EVALUATION MODEL}

The evaluation of tourism destination network marketing system should start from the perspective of comprehensive and practical, set up an effective evaluation. The evaluation model consists of two layers of evaluation index.

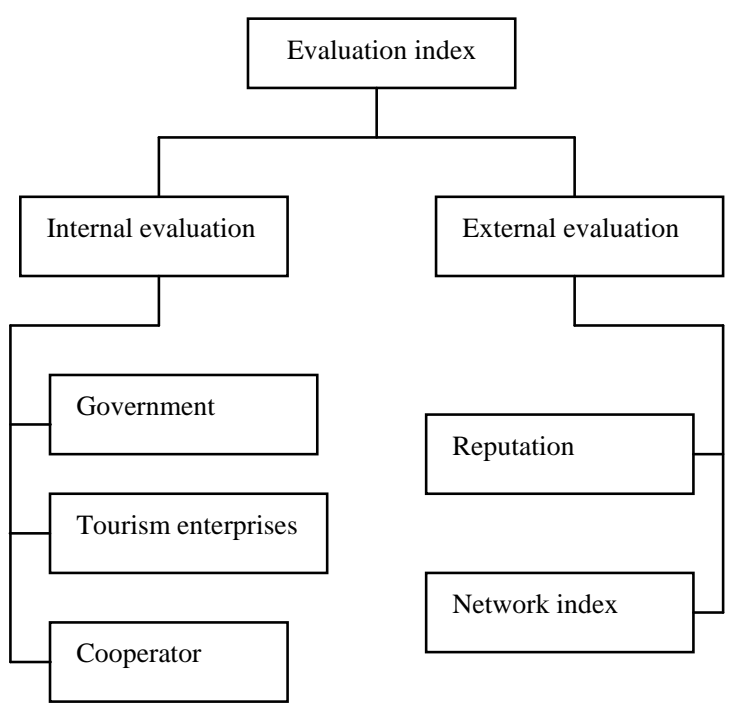

Fig.3 The Evaluation model of tourism destination network marketing system.

\section{A. Internal evaluation}

Internal evaluation index mainly comes from three aspects contains the supervision department of statistics, business data of tourism enterprises and industry cooperation
1) Government supervision: The actively guide and policy support of Government is an important guarantee of the rapid development of the tourism network marketing. The statistical analysis data issued by government departments has credibility and authority. The construction of tourism destination network marketing system under the framework of the wisdom of the city is dominated by the government. The government in the construction of public service platform mainly plays the role of manager. Therefore, the government supervision data is an important part of the tourism enterprise evaluation index.

2) Tourism enterprises: Tourism enterprises as an important participant in the destination network marketing system. They want to use the network marketing platform can improve the business income, to promote corporate image and products to achieve good marketing results. The evaluation of network marketing platform from tourism enterprises is summarized and analyzed from the perspective of business needs, the result is more real and effective.

3) Cooperator: As the partner of the tourism destination network marketing system, They are more concerned with their economic interests whether can be achieved in the cooperation. Their evaluation is more objective, has stronger guiding significance to improvement of tourism destination network marketing platform.

\section{B. External evaluation}

The external evaluation index mainly includes the evaluation of reputation market feedback and the data of network platform.

1) Reputation evaluation: Tourism industry belongs to the service industry. The core competitiveness of the service industry is reflected in the market share and Popularity. The reputation evaluation of tourism enterprises is an important indicator of the status and influence of the tourism industry enterprises. The word of mouth marketing is the economic benefits of tourism destination network marketing system.

2) Network index: The network index is an important part of external evaluation index. Through the statistics of the number of customers online registration, data traffic and web search ranking to determine the index of the tourism destination network marketing system operating efficiency, the real evaluation based on network data, network operators can accurately reflect the benefits of tourism marketing network platform.

\section{CONCLUSION}

The tourism destination network marketing system is the innovation of application framework based on the construction of smart city. With scientific and practical significance for the innovation of tourism marketing, tourism as an important support of national economy, the latest achievements of modern 


information technology based on the whole
industry, vigorously develop the tourism
industry competitiveness and influence is represent the
general trend and the inevitable choice.

\section{ACKNOWLEDGMENT}

This work is supported by Harbin University Youth(master) Scientific Research Fund Project, No. HUYF2014-003

\section{REFERENCES}

[1] Nicos Komninos. The architecture of Intelligent cities Integrating human, collective, and artificial intelligence to enhance knowledge and innovation 2nd International Conference on Intelligent Environments, Institution of Engineering and Technology,Athens,5-6July 2006.

[2] Soonjin Choia , Xinran Y. Lehtoa, Alastair M. Morrisonb. Destination image representation on the web: Content analysis of Macau travel related web-sites. Tourism Management, 2007,28.

[3] Rob Law,Shanshan Qi,Dimitrios Buhalis. Progress in tourism management: A review of website evaluation in tourism research [ J ] .Tourism Management,2010,31:297 - 313.

[4] Bing Pan,Zheng Xiang,Pob Law,Daniel R.Fesenmaier.The Dynamics of Search Engine Marketing for Tourist Destination[ J ] .Journal of Travel Research,2011,50(4):365 - 377.

[5] Leixia Cai,Jaclyn Card,Shu T.Cole. .Content delivery Performance of.Worldwide websites of US tour operators focusing on destinations in China[J] .Tourism Management,2004,25(2):219-227.

[6] Youcheng Wang. Web ` based Destination Marketing Systems: Assessing the Critical Factors for Management and Implementation [J] .International Journal of Tourism Research,2008,10:55 - 70

[7] Buhalis D; Ma Xiaoqiu, Zhang Lingyun ( trans ). Tourism Electronic Commerce : Tourism Information Technology Strategy Management [M].Beijing Tourism Education Press,2004.

[8] Dae-Young Kima, Xinran Y. Lehtob, Alastair M. Morrisonc. Gender differences in online travel information search : Implications for marketing communications on the internet. Tourism Management, 2008,18.

[9] Youcheng Wang, Daniel R. Fesenmaierb. Towards understanding members general participation in and active contribution to an online travel community. Tourism Management, 2012,25.

[10] Wober K W. Information supply in tourism management by marketing decision support systems. Tourism Management, 2013,24:241-255.

[11]VirginiaCano,RichardPrentiee.OPPortunitiesforendearmenttoPlacethro ugheleetronie'visiting':WWWhomePagesandthetourismPromotionofSeotlan d.TourismeManagement.2013,67-70

[12]RobinJ.B.Ritchie,J.R.BrentRitchie.A framework for an industry supported destination marketinginformationsystem[J].TourismManagement,2013,23(5):439-454.

[13]Gle Homby.Adoption of destination marketing systems by tourism operatorsin Australia[J].Sustainabletourismedueation2012,12(9):56-61.

[14]Unai Bastida,T.C. Huan. Performance evaluation of tourism websites' information quality of four global destination brands: Beijing, Hong Kong, Shanghai, and Taipei[J]. Journal of Business Research . 2012.

[15] Douwe van den Brink,Gaby Odekerken-Schröder,Pieter Pauwels. The effect of strategic and tactical cause-related marketing on consumers' brand loyalty[J]. Journal of Consumer Marketing . 2006 (1)

[16] Q Shanshan,Dimitrios Buhalis,Rob Law.Evaluation of the Usability of Chinese Destination Management Organisation Websites. 2014

[17]Buhalis, Pender. L,Sharpley, R.Information and communications technologies for tourism. The management of tourism . 2014.

[18] Hailin Qu,Lisa Hyunjung Kim,Holly Hyunjung Im. A model of destination branding: Integrating the concepts of the branding and destination image[J]. Tourism Management . 2010 (3)
[19] Anca E. Cretu,Roderick J. Brodie. The influence of brand image and company reputation where manufacturers market to small firms: A customer value perspective[J]. Industrial Marketing Management . 2005 (2) 